\title{
Temperature-sensitive oculocutaneous albinism type 1
}

INSERM

\section{Source}

INSERM. (1999). Orphanet: an online rare disease and orphan drug data base.

Temperature-sensitive oculocutaneous albinism type 1. ORPHA:352737

Type 1 temperature sensitive oculocutaneous albinism (OCA1-TS) is an extremely rare form of OCA1 (see this term) characterized by the production of temperature sensitive tyrosinase proteins leading to dark hair on the legs, arms and chest (cooler body areas) and white hair on the scalp, axilla and pubic area (warmer body areas). 